\title{
Index to Volume 47
}

\section{A}

\section{ACADEMIC LIBRARIES}

Asher, Curt, and Emerson Case. A Generation in Transition: A Study of the Usage and Attitudes Toward Public Libraries by Generation 1.5 Composition Students, 47(3):274-279

Bahavar, Shahla, and Judith A. Truelson. Strategic Planning for Reference in a Team Environment: The Preferred Futuring Model, 47(4):356-363

Colson, Jeannie. Determining Use of an Academic Library Reference Collection, 47(2):168-175

Delatte, Monique, and Lore A. Guilmartin. Recommended Core Bibliography of Textile and Clothing Resources for Academic and Public Libraries, 47(4):318-323

Eckel, Edward J. Fostering SelfRegulated Learning at the Reference Desk, 47(1):16-20

Gregory, Cynthia L. "But I Want a Real Book": An Investigation of Undergraduates' Usage and Attitudes toward Electronic Books, 47(3):266-273

Kenney, Barbara Ferrer. Revitalizing the One-Shot Instruction Session Using Problem-Based Learning, 47(4):386-391

MacDonald, Karen I., Wyoma Vanduinkerken, and Jane Stephens. It's All in the Marketing: The Impact of a Virtual Reference Marketing Campaign at Texas A\&M University, 47(4):375-385

Mosley, Pixey Anne. Assessing User Interactions at the Desk Nearest the Front Door, 47(2):159-167

Singer, Carol A. Weeding Gone Wild: Planning and Implementing a Review of the Reference Collection, 47(3):256-264

Wang, Li. Sociocultural Learning Theories and Information Literacy Teaching Activities in Higher
Education, 47(2): 149-158

Accidental Technologist (column)

Stephens, Michael. Taming

Technolust: Ten Steps for

Planning in a 2.0 World, 47(4):314-317

Stormont, Sam. Looking to Connect: Technical Challenges that Impede the Growth of Virtual Reference, 47(2):114-119

Afro-Latinos: An Annotated Guide for Collection Building, 47(1):10-15

Agosto, Denise E., and Holly

Anderton

Whatever Happened to "Always Cite the Source?" 47(1):44-54

The Alert Collector (column)

Delatte, Monique, and Lore A. Guilmartin. Recommended Core Bibliography of Textile and Clothing Resources for Academic and Public Libraries, 47(4):318-323

Dwyer, Tierney V. Unitarian Universalism: A Research Guide, 47(3):210-214

Higgins, Shana M. Afro-Latinos: An Annotated Guide for Collection Building, 47(1):10-15

Wyatt, Neal, Georgine Olson, Kristin Ramsdell, Joyce Saricks, and Lynne Welch. Core Collections in Genre Studies: Romance Fiction 101, 47(2):120-126

Anderton, Holly. See Agosto, Denise E. Antell, Karen, ed.

Professional Materials, 47(1):92-96, 47(2):187-192, 47(3):294-299, 47(4):402-407

Are You Smarter Than a Fifth Grader? 47(1):8-9

Arp, Lori, ed.

Information Literacy and Instruction, 47(1):16-20

Asher, Curt, and Emerson Case

A Generation in Transition: A Study of the Usage and Attitudes Toward Public Libraries by Generation 1.5 Composition Students, 47(3):274-279
Assessing User Interactions at the Desk Nearest the Front Door, 47(2):159-167

\section{B}

Back to the Future? A Response to Dilevko and Magowan, 47(2):127-131

Bahavar, Shahla, and Judith A. Truelson Strategic Planning for Reference in a Team Environment: The Preferred Futuring Model, 47(4):356-363

Ball, Andrew

Letter to the Editor, 47(1):7

Beard, David, and Kate Vo Thi-Beard Rethinking the Book: New Theories for Readers' Advisory, 47(4):331-335

Best Bibliographies in History, 47(1):32-34

Best Free Reference Web Sites, 47(1):36-41

BIBLIOGRAPHIC INSTRUCTION Desai, Christina M., and Stephanie J. Graves. Cyberspace or Face-toFace: The Teachable Moment and Changing Reference Mediums, 47(3):242-250, 252-255

Eckel, Edward J. Fostering SelfRegulated Learning at the Reference Desk, 47(1):16-20

Kenney, Barbara Ferrer. Revitalizing the One-Shot Instruction Session Using Problem-Based Learning, 47(4):386-391

BOOK DISCUSSION GROUPS

Taylor, Joan Bessman. Good for What? Non-appeal, Discussibility, and Book Groups (Part 2), 47(1):26-31

BUSINESS REFERENCE SERVICES

BRASS Business Reference Sources Committee. Outstanding Business Reference Sources, 47(2):132-136

"But I Want a Real Book": An Investigation of Undergraduates' Usage and Attitudes toward Electronic Books, 47(3):266-273 


\section{CANADIAN HEALTH INFORMATION}

Harris, Roma, and Nadine Wathen. "If My Mother Was Alive I'd Probably Have Called Her.": Women's Search for Health Information in Rural Canada, 47(1):67-79

Case, Emerson. See Asher, Curt CHAT REFERENCE SERVICES. See VIRTUAL REFERENCE SERVICES COLLECTION DEVELOPMENT

Colson, Jeannie. Determining Use of an Academic Library Reference Collection, 47(2): 168-175

Gregory, Cynthia L. "But I Want a Real Book": An Investigation of Undergraduates' Usage and Attitudes toward Electronic Books, 47(3):266-273

Singer, Carol A. Weeding Gone Wild: Planning and Implementing a Review of the Reference Collection, 47(3):256-264

Collection-Related Courses in ALAAccredited Master's Programs, 47(1):42-43

Colson, Jeannie

Determining Use of an Academic Library Reference Collection, 47(2):168-175

Comparison of Retrieval Performance of Eleven Online Indexes Containing Information Related to Quaternary Research, an Interdisciplinary Science, 47(1):56-65

Cooperative Reference Services Committee

Guidelines for Cooperative Reference Services, 47(1):97-100

Core Collections in Genre Studies: Romance Fiction 101, 47(2):120-126

CUSTOMER SERVICE

Saunders, E. Stewart. The LibQUAL+ Phenomenon: Who Judges Quality? 47(1):21-24

Cyberspace or Face-to-Face: The Teachable Moment and Changing Reference Mediums, 47(3):242-250, 252-255

\section{D}

Delatte, Monique, and Lore A.

Guilmartin

Recommended Core Bibliography of Textile and Clothing Resources for Academic and Public Libraries, 47(4):318-323
Desai, Christina M., and Stephanie J. Graves

Cyberspace or Face-to-Face: The Teachable Moment and Changing Reference Mediums, 47(3):242-250, 252-255

Determining Use of an Academic Library Reference Collection, 47(2):168-175

DIGITAL REFERENCE SERVICES. See VIRTUAL REFERENCE SERVICES

Dwyer, Tierney V.

Unitarian Universalism: A Research Guide, 47(3):210-214

\section{E}

E-BOOKS

Gregory, Cynthia L. "But I Want a Real Book": An Investigation of Undergraduates' Usage and Attitudes toward Electronic Books, 47(3):266-273

Eckel, Edward J. Fostering Self-Regulated Learning at the Reference Desk, 47(1):16-20

Education for Readers' Advisory Service in Library and Information Science Programs, 47(3):224-229

The Effects of Librarians' Behavioral Performance on User Satisfaction in Chat Reference Services, 47(2):137-148

ENGLISH AS A SECOND

LANGUAGE

A Generation in Transition: A Study of the Usage and Attitudes Toward Public Libraries by Generation 1.5 Composition Students, 47(3):274-279

Everyday Miracles, 47(4):311-313

\section{$\mathbf{F}$}

Ford, Charlotte, E., ed. For Your Enrichment (column), 47(4):324-330

For Your Enrichment (column)

Gerardin, Julie, Michelle Yamamoto, and Kelly Gordon. Fresh Perspectives on Reference Work in Second Life, 47(4):324-330

Martin, Michele. The Man Behind the Slam: An Interview with Bill Pardue, 47(3):216-217

Fostering Self-Regulated Learning at the Reference Desk, 47(1):16-20

From Committees of RUSA. See also Guidelines CODES Collection Development Education Committee. CollectionRelated Courses in ALA-
Accredited Master's Programs, 47(1):42-43

RUSA BRASS Business Reference Sources Committee. Outstanding Business Reference Sources, 47(2):132-136

RUSA CODES Reference Sources Committee. Outstanding Reference Sources: The 2008 Selection of Titles, 47(4):338

RUSA History Section Bibliography and Indexes Committee. Best Bibliographies in History, 47(1):32-34

RUSA Machine-Assisted Reference Section (MARS). Best Free Reference Web Sites, 47(1):36-41

RUSA Notable Books Council. Notable Books: The 2008 Selection of Titles, 47(4):336-337

RUSA Reading List Council. The Reading List 2008, 47(4):339-340

From the Editor (column)

An Interview with 2006-2007 ALISE President Connie Van Fleet, 47(3):204-206

It Almost Takes a Village, 47(4):307-309

O'Connor, Lisa. "Nice Shoes," 47(1):4-6

A Reference Renaissance, 47(2):108-110

From the President of RUSA (column)

Are You Smarter Than a Fifth Grader? 47(1):8-9

Everyday Miracles, 47(4):311-313

That Thing You Do, 47(2):111-113

Why is Germany in Europe? And Other Lessons from a Life in Reference, 47(3):207-209

\section{G}

A Generation in Transition: A Study of the Usage and Attitudes toward Public Libraries by Generation 1.5 Composition Students, 47(3):274-279

Good for What? Non-appeal, Discussibility, and Book Groups (Part 2), 47(1):26-31

Gordon, Kelly. See Gerardin, Julie

Graves, Stephanie J. See Desai, Christina A.

Gregory, Cynthia L.

"But I Want a Real Book": An Investigation of Undergraduates Usage and Attitudes toward Electronic Books, 47(3):266-273

Gregory, Vicki L. See Kwon, Nahyun GUIDELINES 


\section{INDEX TO VOLUME 47}

Guidelines for Cooperative Reference Services, 47(1):97-100

Guidelines for Library Services to Spanish-Speaking Library Users, 47(2):194-197

Guidelines for the Development and Promotion of Multilingual Collections and Services, 47(2):198-200

Guilmartin, Lore A. See DeLatte, Monique; Delatte, Monique

\section{$\mathrm{H}$}

Harris, Roma, and Nadine Wathen

"If My Mother Was Alive I'd Probably Have Called Her.": Women's Search for Health Information in Rural Canada, 47(1):67-79

HEALTH INFORMATION SERVICES Harris, Roma. "If My Mother Was Alive I'd Probably Have Called Her.": Women's Search for Health Information in Rural Canada, 47(1):67-79

Henry, Deborah B., and Tina M. Neville

Testing Classification Systems for Reference Questions, 47(4):364-373

Higgins, Shana M.

Afro-Latinos: An Annotated Guide for Collection Building, 47(1):10-15

Hollands, Neil

Back to the Future? A Response to Dilevko and Magowan, 47(2):127-131

I

"If My Mother Was Alive I'd Probably Have Called Her.": Women's Search for Health Information in Rural Canada, 47(1):67-79

INFORMATION LITERACY

Wang, Li. Sociocultural Learning Theories and Information Literacy Teaching Activities in Higher Education, 47(2):149-158

Information Literacy and Instruction (column)

Eckel, Edward J., Fostering SelfRegulated Learning at the Reference Desk, 47(1):16-20

Instructions to Authors, 47(1):101-103

An Interview with 2006-2007 ALISE President Connie Van Fleet, 47(3):204-206

Isaacson, David

Letter to the Editor, [comment on 46(2):22-26], 47(1):7
It Almost Takes a Village, 47(4):307-309

It's All in the Marketing: The Impact of a Virtual Reference Marketing Campaign at Texas A\&M

University, 47(4):375-385

\section{J}

Joseph, Lura E.

Comparison of Retrieval Performance of Eleven Online Indexes Containing Information Related to Quaternary Research, an Interdisciplinary Science, 47(1):56-65

\section{K}

Kenney, Barbara Ferrer

Revitalizing the One-Shot Instruction Session Using Problem-Based Learning, 47(4):386-391

Kern, M. Kathleen, ed.

Accidental Technologist (column), 47(2):114-119, 47(4):313-317

Kwon, Nahyun, and Vicki L. Gregory The Effects of Librarians' Behavioral Performance on User Satisfaction in Chat Reference Services, 47(2):137-148

\section{L}

LETTERS TO THE EDITOR Ball, Andrew, 47(1):7 Isaacson, David, 47(1):7

The LibQUAL+ Phenomenon: Who Judges Quality? 47(1):21-24

LIBRARY SCIENCE EDUCATION O'Connor, Lisa. "Nice Shoes," $47(1): 4-6$

Van Fleet, Connie. Education for Readers' Advisory Service in Library and Information Science Programs, 47(3):224-229

Looking to Connect: Technical Challenges that Impede the Growth of Virtual Reference, 47(2):114-119

\section{M}

MacDonald, Karen I., Wyoma Vanduinkerken, and Jane Stephens It's All in the Marketing: The Impact of a Virtual Reference Marketing Campaign at Texas A\&M University, 47(4):375-385

Management (column)

Miller, Jonathan. Quick and Easy Reference Evaluation: Gathering Users' and Providers' Perspectives, 47(3):218-222

Saunders, E. Stewart. The LibQUAL+
Phenomenon: Who Judges Quality? 47(1):21-24

The Man Behind the Slam: An Interview with Bill Pardue, 47(3):216-217

MARKETING

MacDonald, Karen I., Wyoma Vanduinkerken, and Jane Stephens. It's All in the Marketing: The Impact of a Virtual Reference Marketing Campaign at Texas A\&M University, 47(4):375-385

Miller, Jonathan

Quick and Easy Reference Evaluation: Gathering Users' and Providers' Perspectives, 47(3):218-222

Mosley, Pixey Anne

Assessing User Interactions at the Desk Nearest the Front Door, 47(2):159-167

MULTILINGUAL COLLECTIONS

Library Services to the SpanishSpeaking Committee. Guidelines for the Development and Promotion of Multilingual Collections and Services, 47(2):198-200

\section{N}

Naylor, Sharon, Bruce Stoffel, and Sharon Van Der Laan Why Isn't Our Chat Reference Used More? 47(4):342-354

Neville, Tina M. See Henry, Deborah B. "Nice Shoes," 47(1):4-6

Nixon, Judith M., ed.

Management (column), 47(1):21-24, 47(3):218-222

O'Connor, Lisa

"Nice Shoes," 47(1):4-6

Olson, Georgine. See Wyatt Neal

Outstanding Reference Sources: The 2008 Selection of Titles, 47(4):338

PROBLEM BASED LEARNING

Kenney, Barbara Ferrer. Revitalizing the One-Shot Instruction Session Using Problem-Based Learning, 47(4):386-391

PUBLIC LIBRARIES

Agosto, Denise E. Whatever Happened to "Always Cite the Source?" 47(1):44-54

Asher, Curt., and Emerson Case. A Generation in Transition: A Study of the Usage and Attitudes Toward Public Libraries by Generation 
1.5 Composition Students, 47(3):274-279

Beard, David, and Kate Vo ThiBeard. Rethinking the Book: New Theories for Readers' Advisory, 47(4):331-335

Delatte, Monique, and Lore A. Guilmartin. Recommended Core Bibliography of Textile and Clothing Resources for Academic and Public Libraries, 47(4):318-323

\section{Q}

Quick and Easy Reference Evaluation: Gathering Users' and Providers' Perspectives, 47(3):218-222

\section{$\mathbf{R}$}

Radcliff, Carolyn J. ed.

Reference Books, 47(1):81-92, 47(3):281-294, 47(4):393-402

Radcliff, Carolyn J. ed. Reference Books, 47(2):177-187

Ramsdell, Kristin. See Wyatt, Neal Readers' Advisory

RUSA Reading List Council. The Reading List 2008, 47(4):339-340

Readers' Advisory (column)

Beard, David, and Kate Vo ThiBeard. Rethinking the Book: New Theories for Readers' Advisory, 47(4):331-335

Hollands, Neil. Back to the Future? A Response to Dilevko and Magowan, 47(2):127-131

Taylor, Joan Bessman. Good for What? Non-appeal, Discussibility, and Book Groups (Part 2), 47(1):26-31

Van Fleet, Connie. Education for Readers' Advisory Service in Library and Information Science Programs, 47(3):224-229

Recommended Core Bibliography of Textile and Clothing Resources for Academic and Public Libraries, 47(4):318-323

A Reference Renaissance, 47(2):108-110

\section{REFERENCE SERVICES}

Agosto, Denise E. Whatever Happened to "Always Cite the Source?" 47(1):44-54

Are You Smarter Than a Fifth Grader? 47(1):8-9

Bahavar, Shahla, and Judith A. Truelson. Strategic Planning for Reference in a Team Environment: The Preferred Futuring Model,
47(4):356-363

Cooperative Reference Services Committee. Guidelines for Cooperative Reference Services, 47(1):97-100

Desai, Christina M., and Stephanie J. Graves. Cyberspace or Face-toFace: The Teachable Moment and Changing Reference Mediums, 47(3):242-250, 252-255

Eckel, Edward J. Fostering SelfRegulated Learning at the Reference Desk, 47(1):16-20

Henry, Deborah B., and Tina M. Neville. Testing Classification Systems for Reference Questions, 47(4):364-373

Kwon, Nahyun, and Vicki L. Gregory. The Effects of Librarians' Behavioral Performance on User Satisfaction in Chat Reference Services, 47(2): 137-148

Miller, Jonathan. Quick and Easy Reference Evaluation: Gathering Users' and Providers' Perspectives, 47(3):218-222

Singer, Carol A. Weeding Gone Wild: Planning and Implementing a Review of the Reference Collection, 47(3):256-264

Tyckoson, David A. Everyday Miracles, 47(4):311-313

Tyckoson, David A. Why is Germany in Europe? And Other Lessons from a Life in Reference, 47(3):207-209

Zabel, Diane. A Reference Renaissance, 47(2):108-110

Reference Transaction Handoffs: Factors Affecting the Transition from Chat to E-Mail, 47(3):230-241

Revitalizing the One-Shot Instruction Session Using Problem-Based Learning, 47(4):386-391

ROMANCE FICTION

Wyatt, Neal, Georgine Olson, Kristin Ramsdell, Joyce Saricks, and Lynne Welch. Core Collections in Genre Studies: Romance Fiction

RUSA 101, 47(2):120-126

BRASS Business Reference Sources Committee. Outstanding Business Reference Sources, 47(2):132-136

CODES Collection Development Education Committee. CollectionRelated Courses in ALAAccredited Master's Programs, 47(1):42-43
RUSA CODES Reference Sources Committee. Outstanding Reference Sources: The 2008 Selection of Titles, 47(4):338

RUSA History Section Bibliography and Indexes Committee. Best Bibliographies in History, 47(1):32-34

RUSA Machine-Assisted Reference Section (MARS). Best Free Reference Web Sites, 47(1):36-41

RUSA Notable Books Council. Notable Books: The 2008 Selection of Titles, 47(4):336-337

RUSA Reading List Council. The Reading List 2008, 47(4):339-340

$\mathbf{S}$

Saricks. Joyce. See Wyatt, Neal

Saunders, E. Stewart

The LibQUAL+ Phenomenon: Who Judges Quality? 47(1):21-24

SECOND LIFE (VIRTUAL WORLD)

Gerardin, Julie, Michelle Yamamoto, and Kelly Gordon. Fresh Perspectives on Reference Work in Second Life, 47(4):324-330

Singer, Carol A.

Weeding Gone Wild: Planning and Implementing a Review of the Reference Collection, 47(3):256-264

Sociocultural Learning Theories and Information Literacy Teaching Activities in Higher Education, 47(2):149-158

SPANISH LANGUAGE LIBRARY SERVICES

Library Services to the SpanishSpeaking Committee. Guidelines for Library Services to SpanishSpeaking Library Users, 47(2):194-197

Stephens, Jan. See Macdonald, Karen I.

Stephens, Michael

Taming Technolust: Ten Steps for Planning in a 2.0 World, 47(4):314-317

Stoffel, Bruce. See Naylor, Sharon

Stormont, Sam

Looking to Connect: Technical Challenges that Impede the Growth of Virtual Reference, 47(2):114-119

Strategic Planning for Reference in a Team Environment: The Preferred Futuring Model, 47(4):356-363

T

Taming Technolust: Ten Steps 


\section{INDEX TO VOLUME 47}

for Planning in a 2.0 World, 47(4):314-317

Taylor, Joan Bessman.

Good for What? Non-appeal, Discussibility, and Book Groups (Part 2), 47(1):26-31

TELEPHONE REFERENCE SERVICES

Agosto, Denise E. Whatever Happened to "Always Cite the Source?" 47(1):44-54

Testing Classification Systems for Reference Questions, 47(4):364-373

That Thing You Do, 47(2):111-113

Thi-Beard, Kate Vo. See Beard, David

Trott, Barry, ed.

Readers' Advisory (column), 47(1):26-31, 47(3):224-229, 47(4):331-335

Truelson, Juudith A. See Bahavar, Shahla

Tyckoson, David A.

Are You Smarter Than a Fifth Grader? 47(1):8-9

Everyday Miracles, 47(4):311-313

That Thing You Do, 47(2):111-113

Why is Germany in Europe? And Other Lessons from a Life in Reference, 47(3):207-209

\section{U}

Unitarian Universalism: A Research Guide, 47(3):210-214

\section{V}

Van Der Laan, Sharon. See Naylor, Sharon

VanDuinkerken, Wyoma. See Macdonald, Karen I.

Van Fleet, Connie

Education for Readers' Advisory Service in Library and Information Science Programs, 47(3):224-229

VIRTUAL REFERENCE SERVICES

Desai, Christina M., and Stephanie J. Graves. Cyberspace or Face-toFace: The Teachable Moment and Changing Reference Mediums, 47(3):242-250, 252-255

Gerardin, Julie, Michelle Yamamoto, and Kelly Gordon. Fresh Perspectives on Reference Work in Second Life, 47(4):324-330

Kwon, Nahyun, and Vicki L. Gregory. The Effects of Librarians' Behavioral Performance on User Satisfaction in Chat Reference Services, 47(2):137-148

Martin, Michele. The Man Behind the Slam: An Interview with Bill

Pardue, 47(3):216-217

Naylor, Sharon, Bruce Stoffel, and Sharon Van Der Laan. Why Isn't Our Chat Reference Used More? 47(4):342-354

Stormont, Sam. Looking to Connect: Technical Challenges that Impede the Growth of Virtual Reference, 47(2):114-119

Wikoff, Nora. Reference Transaction Handoffs: Factors Affecting the Transition from Chat to E-Mail, 47(3):230-241

Zabel, Diane. A Reference Renaissance, 47(2):108-110

\section{W}

Wang, Li

Sociocultural Learning Theories and Information Literacy Teaching Activities in Higher Education, 47(2):149-158

Wathen, Nadine. See Harris, Roma WEB 2

Tyckoson, David A. That Thing You Do, 47(2):111-113

\section{WEB RESOURCES}

Best Free Reference Web Sites, 47(1):36-41

Joseph, Lura E. Comparison of Retrieval Performance of Eleven Online Indexes Containing Information Related to Quaternary Research, an Interdisciplinary Science, 47(1):56-65

Weeding Gone Wild: Planning and Implementing a Review of the Reference Collection, 47(3):256-264

Welch, Lynne. See Wyatt, Neal

Whatever Happened to "Always Cite the Source?" 47(1):44-54

Why is Germany in Europe? And Other Lessons from a Life in Reference, 47(3):207-209

Why Isn't Our Chat Reference Used More? 47(4):342-354

Wikoff, Nora Reference Transaction Handoffs: Factors Affecting the Transition from Chat to E-Mail, 47(3):230-241

WOMEN'S HEALTH INFORMATION Harris, Roma, and Nadine Wathen. "If My Mother Was Alive I'd Probably Have Called Her.": Women's Search for Health Information in Rural Canada, 47(1):67-79
Woodard, Beth S., ed.

Information Literacy and Instruction, $47(1): 16-20$

Wyatt, Neal, ed.

The Alert Collector (column), 47(1):10-15, 47(3):210-214

Wyatt, Neal, Wyatt, Neal, Georgine Olson, Kristin Ramsdell, Joyce

Saricks, and Lynne Welch

Core Collections in Genre Studies: Romance Fiction 101, 47(2):120-126

\section{$Y$}

Yamamoto, Michelle. See Gerardin, Julie

\section{Z}

Zabel, Diane

From the Editor, 47(1):4-6, 47(2):108-110, 47(3):204-206, 47(4):307-309

Zabel, Diane, ed.

For Your Enrichment (column), 47(3):216-217

\section{SOURCES}

\section{A}

Academic Librarianship by Design: A Blended Librarian's Guide to the Tools and Techniques, 47(4):402

African Americans in the Media Today: An Encyclopedia, 47(4):393

Almanac of the 50 States: Basic Data Profiles with Comparative Tables, 47(3):281

Alternative Publishers of Books in North America, 47(3):294

Analyses of Nineteenth- and Twentieth-Century Music, 1940-2000, 47(3):281

Archives and the Digital Library, 47(3):294-295

Art Museum Libraries and Librarianship, 47(3):295

Asian Americans: A Statistical Sourcebook, 47(3):281-282

\section{B}

Barbarians at the Gates of the Public Library: How Postmodern Consumer Capitalism Threatens Democracy, Civil Education, and the Public Good, 47(4):402-403

Best Books for Children: Preschool through Grade 6, 47(2):187

Beyond Survival: Managing Academic Libraries in Transition, 47(2):187-188

The Big Book of Teen Reading Lists, 
47(4):403

Biotechnology: Changing Life through Science, 47(2): 177

Black American Military Leaders: A Biographical Dictionary, 47(3):282

Black Americans A Statistical Sourcebook, 47(3):282-283

The Blue Book on Information Age Inquiry, Instruction, and Literacy, 47(1):92-93

Books Kids Will Sit Still For 3: A Read-Aloud Guide, 47(1):93

Booktalks and Beyond: Promoting Great Genre Reads to Teens, 47(3):295-296

British and Irish Poets: A Biographical Dictionary, 449-2006, 47(3):283

Build It Once: A Basic Primer for the Creation of Online Exhibitions, 47(4):403

\section{C}

The Cambridge Encyclopedia of Stars, 47(1):81

The Cambridge History of Libraries in Britain and Ireland, 47(3):296

Career Opportunities in Conservation and the Environment, 47(4):393

Cities of the Middle East and North Africa: A Historical Encyclopedia, 47(3):283-284

Civil Wars of the World: Major Conflicts Since World War II, 47(2):177-178

Collection Development Issues in the Online Environment, 47(1):93-94

Crash Course in Storytelling, 47(2): 188

Crash Course in Web Design for Libraries, 47(2):188

Cuba: A Global Studies Handbook, 47(4):393-394

\section{D}

A Day in the Life: Career Opportunities in Library and Information Science, 47(3):296-297

Drugs and Sports, 47(2):178

\section{$E$}

Encyclopedia of Activism and Social Justice, 47(4):394

Encyclopedia of American Folklore, 47(2):178-179

Encyclopedia of American Indian History, 47(3):284-285

Encyclopedia of American Indian Literature, 47(3):285

Encyclopedia of American Jewish
History, 47(3):285-286

The Encyclopedia of American Law Enforcement, 47(1):81-82

Encyclopedia of American Urban History, 47(1):82

Encyclopedia of Asian-American Literature, 47(4):394-395

The Encyclopedia of Autism Spectrum Disorders, 47(1):82-83

Encyclopedia of Beat Literature, 47(2): 179

Encyclopedia of Business Ethics and Society, 47(4):395-396

Encyclopedia of Catholicism, 47(2):179-180

Encyclopedia of Catholic Social Thought, Social Science, and Social Policy, 47(4):396

Encyclopedia of Children, Adolescents, and the Media, 47(3):286

Encyclopedia of Contemporary Russian Culture, 47(3):286-287

Encyclopedia of Emancipation and Abolition in the Transatlantic World, 47(3):287-288

Encyclopedia of Environment and Society, 47(4):396

Encyclopedia of Evolution, 47(1):83

Encyclopedia of Globalization, 47(2): 180

Encyclopedia of Health and Aging, 47(2):180-181

Encyclopedia of Human-Animal Relationships: A Global Exploration of Our Connections with Animals, 47(4):397

Encyclopedia of Italian Literary Studies, 47(1):83-84

Encyclopedia of Law and Society: American and Global Perspectives, 47(3):288

Encyclopedia of Nineteenth-Century Photography, 47(4):397-398

Encyclopedia of the Modern World, 47(1):84-85

Encyclopedia of World Constitutions, 47(2): 181

Encyclopedia of World War II, 47(4):398

Energy Use Worldwide, 47(3):288-289

\section{$\mathrm{F}$}

The Facts on File Encyclopedia of Health and Medicine: Comprehensive and Concise Guide to the Human Body and Modern Medical Practices, 47(1):85

The Fourth of July Encyclopedia, 47(2):181-182

\section{G}

Gotcha for Guys!: Nonfiction Books to Get Boys Excited about Reading, 47(2):188-189

Graphic Novels: A Genre Guide to Comic Books, Manga, and More, 47(3):297

Great Events from History: Gay, Lesbian, Bisexual, Transgender Events, 1846-2006, 47(2):182-183

Great Lives from History: Notorious Lives, 47(1):85-86

The Greenwood Encyclopedia of World Popular Culture, 47(3):289

The Grove Encyclopedia of Classical Art and Architecture, 47(3):289-290

The Guy-Friendly YA Library: Serving Male Teens, 47(3):297

$\mathrm{H}$

Historical Dictionary of Renaissance Art, 47(4):398-399

Homelessness Handbook, 47(2):183

\section{I}

Icons of Hip Hop: An Encyclopedia of the Movement, Music, and Culture, 47(3):290

Information Literacy and the School Media Center, 47(1):94

Intellectual Property: Everything the Digital-Age Librarian Needs to Know, 47(4):403-404

International Encyclopedia of Men and Masculinities, 47(3):290-291

International Encyclopedia of Social Policy, 47(3):291

Inventors and Inventions, 47(4):399

\section{J}

J. R. R. Tolkien Encyclopedia: Scholarship and Critical Assessment, 47(3):291-292

$\mathrm{K}$

The Korean War: An Exhaustive Chronology, 47(4):399-400

The Ku Klux Klan: History, Organization, Language, Influence, and Activities of America's Most Notorious Secret Society, 47(1):86

\section{L}

Latinos in the Arts, 47(2):183-184

Law Librarianship in the Twenty-First Century, 47(2):189

Leadership Basics for Librarians and Information Professionals, 47(4):404 


\section{INDEX TO VOLUME 47}

Libraries and Google, 47(1):94

Libraries and Librarianship: Sixty Years of Challenge and Change, 1945-2005, 47(3):297-298

Libraries Beyond their Institutions: Partnerships That Work, 47(2): 189-190

Library Board Strategic Guide, 47(3):298

Library Collection Development Policies: School Libraries and Learning Resource Centers, 47(3):298-299

Library Juice Concentrate, 47(2):190-191

Library Services for the Incarcerated: Applying the Public Library Model in Correctional Facility Libraries, 47(1):94-95

The Library as Place: History, Community, and Culture, 47(2): 190

Literature Search Strategies for Interdisciplinary Research: A Sourcebook for Scientists and Engineers, 47(1):95

The Lore of Ireland: An Encyclopedia of Myth, Legend, and Romance, $47(2): 184$

\section{M}

Making a Difference: Leadership and Academic Libraries, 47(3):299

Managing Facilities for Results: Optimizing Space for Services, 47(3):299

Material Culture in America: Understanding Everyday Life, 47(4):400

McGraw-Hill Encyclopedia of Science and Technology, 10th Edition, 47(3):292

Milestones in Archaeology: A Chronological Encyclopedia, 47(2):184-185

\section{N}

New Encyclopedia of Africa, 47(4):400-401

New Makers of Modern Culture, 47(1):86-87
New on the Job: A School Library Media Specialist's Guide to Success, 47(4):405

The New Inquisition: Understanding and Managing Intellectual Freedom Challenges, 47(4):404-405

Notable Natural Disasters, 47(3):292 294

Opera: An Encyclopedia of World Premieres and Significant Performances, Singers, Composers, Librettists, Arias, and Conductors, 1597-2000, 47(1):87

Origins and Development of Musical Instruments, 47(4):401-402

Out Front with Stephen Abram: A Guide for Information Leaders, 47(2):191

The Oxford Companion to Black British History, 47(2):185

The Oxford Companion to World Exploration, 47(1):87-88

The Oxford Encyclopedia of Maritime History, 47(2):185-186

A Passion for Print: Promoting Reading and Books to Teens, 47(1):95

A Practical Guide to Information Literacy Assessment for Academic Librarians, 47(4):405

\section{R}

Radio Frequency Identification Handbook for Librarians, 47(4):405-406

Read 'Em Their Writes: A Handbook for Mystery and Crime Fiction Book Discussions, 47(4):406

Reading Raps: A Book Club Guide for Librarians, Kids, and Families, 47(2):191-192

Religion and the Law in America: An Encyclopedia of Personal Belief and Public Policy, 47(2):186

Religion in America, 47(2):186-187

Renaissance and Reformation,
47(1):88-89

Revolutionary War Almanac [correction], 47(2):187

$\mathrm{S}$

Schirmer Encyclopedia of Film, 47(1):89

Science, Religion, and Society: An Encyclopedia of History, Culture, and Controversy, 47(1):89-90

Serving Young Teens and 'Tweens, 47(2):192

Sex, Brains, and Video Games: A Librarian's Guide to Teens in the Twenty-First Century, 47(4):406

Social Dancing in America: A History and Reference, 47(1):90

Something to Talk about: Creative Booktalking for Adults, 47(2):192

Sport in Ancient Times, 47(1):90-91

Stories on the Move: Integrating Literature and Movement with Children, from Infants to Age 14, 47(4):406-407

\section{T}

Technology and the School Library, 47(4):407

Technology Made Simple: An Improvement Guide for Small and Medium Libraries, 47(1):95-96

\section{U}

U.S. Presidents and Foreign-Policy: from 1789 to the Present, 47(1):91

The U.S. Supreme Court, 47(1):91-92

Understanding Manga and Anime, 47(4):407

\section{W}

World and Its Peoples: Middle East, Western Asia, and Northern Africa, 47(1):92

\section{Y}

A Year of Programs for Teens, 47(1):96 